\title{
PERCEPTIONS OF TEENAGE WOMEN ABOUT EARLY MARRIAGE IN BANGLADESH
}

\author{
Sultana, A. M. ${ }^{1}$ \\ Faculty of Arts and Social Science, \\ Universiti Tunku Abdul Rahman Malaysia (UTAR), Malaysia. \\ (Email: sultana@utar.edu.my) \\ Salam, A. M. ${ }^{2}$ \\ Bangladesh Social Development Academies, Eidgah Residential Area, Bangladesh. \\ (Email: bsdabd@yahoo.com)
}

Received date: $23-05-2019$

Revised date: $29-05-2019$

Accepted date: 10-07-2019

Published date: 15-09-2019

To cite this document: Sultana, A.M., \& Salam, A. M. (2019). Perceptions of Teenage Women About Early Marriage in Bangladesh. International Journal of Education, Psychology and Counseling, 4 (32), 174-179.

DOI: $10.35631 /$ IJEPC.4320017

Abstract: Despite the alarming trend of increased marriage age in many societies, early marriage is still a serious issue in Bangladesh. The significant numbers of women being married before the age of 18. The study determines young women's experience and perception of early marriage. Young married women's perception and experiences were measured using a series of the statement. According to the results, the majority of the participants supported arranged marriage. The results also revealed that early marriage impact on decision making, education, unfulfilled dream, unwanted pregnancies, and marital satisfaction. Given that early marriage is a negative impact, a multidimensional approach is necessary to support and empower disadvantaged women.

Keywords: Early Marriage, Decision making, Unwanted Pregnancies, Unfulfilled Dreams

\section{Introduction}

The term 'early marriage' refers to both formal marriages and informal unions in which a girl is married before the age of 18 (UNICEF, 2005). Early marriage is extremely prevalent in some regions of the world, particularly in developing countries such as India, Bangladesh, Pakistan, Africa and South East Asia. Considering the frequency of early marriages, Bangladesh ranks the fourth highest globally (ICRW, 2012). Adolescent girls in Bangladesh are married soon after reaching puberty and a large number of these young brides are concentrated in the Western and Southern parts of Bangladesh. Although early marriage is not legally prohibited in Bangladesh, they still occur in both the urban and rural areas (Nahid, 2013). According to the Child Marriage Restraint Act 1929, the minimum legal age for marriage is 18 years for females in Bangladesh. However, these laws have little impact on the frequency of early marriages in 
Bangladesh. In most cases, marriages take place between younger couples and with parental consent. Early marriage is a worldwide problem associated with a range of health and social consequences for teenage girls.

In Bangladesh, early marriage is rooted in social-cultural practices and religious beliefs in many communities, most families prepared girls for marriage first (Sultana, 2010). According to religious rules, boys and girls should marry as soon as possible. It is most common among the poor who have fewer resources and opportunities to invest in alternative options for girls (Jennifer et al, 2015). Early marriage is affected by the family's monthly income and religion (Sarker \& Mustafizur, 2012). It has been noted that economically disadvantaged families tended to marry earlier as compared with those from advanced families (Synder et al. 2004). It is crucial to challenge socioeconomic, religious and cultural practices or norms associated with early marriages. There is a greater challenge to traditional beliefs on early marriage in Bangladesh (Sultana \& Salam, 2017).

However, early marriage tends to have several negative impacts on women. A number os studies (Field and Ambrus, 2008; Nguyen and Wodon, 2015) showed that when a girl marries early, the more likely it is that she will have a low level of schooling. According to Jennifer et al, (2015) early marriage can affect girl's physical and mental well-being in a number of ways. A number of studies supported that girls who are married young age experience higher rates of malnutrition, isolation, and depression and higher maternal mortality and morbidity than girls who marry after age 18 (Le Strat, Dubertret \& Nour, 2009). Some studies show negative impacts on women maternal health such as women depression and domestic violence (Sultana and Salam, 2018). Early marriage denies young girls their childhood, their education and, in turn, their futures (UNFPA 2012). The present study attempts to determine young women's experience and perception of early marriage. The importance of this study lies in the fact that instead of relying on quantitative study only, a qualitative method and in-depth interviews were used to uncover the inner experience of teenage women.

\section{Material and Methods}

One-shot cross-sectional survey research design was employed in this paper. The paper is based on both qualitative and quantitative data collections. The qualitative information was collected through in-depth interview while the quantitative information was collected using questionnaire. Quantitative data was analysed percentage, frequency, mean and Standard Deviation while a conventional content analysis approach was used in this qualitative study. The participants comprised of teenage married women who were selected purposefully in Dinajpur, a small city in northern Bangladesh. There are five slum areas in Dinajpur namely; Balubari, Paharpur, Munshipara, kumarpara and Koshba have been chosen as study areas. Data was collected from November 2017 to January 2018. Thirty young married women participated in semi-structured, and 10 women in-depth, individual face to face interviews. The average length of each interview was 40 minutes. Interviews lasted until data saturation.

\section{Results and Discussion}

This study highlights the perception of young women about marriage in the Bangladeshi setting. During the data analysis, three are eight categories were extracted consist of included "acceptance of arranged marriage", "decision-making power" "lack of independence" "unfulfilled dreams" "burden of marital life" "unwanted pregnancy" and "forced to leave school". The results are presented in Table 1. 


\section{Acceptance of Arranged Marriage}

Exploration of attitudes towards arranged marriages was examined from the perspective of young women living in urban community. The results indicated that Bangladeshi women are perceived to be resistant to cultural change. Most Bangladeshi women are supporting arranged marriage. They tended to have high self-expression on marriage arrangement. Bangladesh has changed a lot last few decades, women remain traditional values and norms in marriage. This may be the fact that the more rigid sex-role stereotypes, and the patriarchal, non-egalitarian expectations directed towards women may explain the reason why most women in our study felt satisfied with the decision of their parents (Muazzam et al, 2014).

\section{Decision-Making Power}

Because of their early marriage, low education level, no economic contribution to family, most of participants felt that they had a little role in decision-making. The results revealed that $69.7 \%$ of respondents stated that they tended to have "No" decision-making power. During the indepth interview, a 15 years participant who stated "I have no control at home. I need to seek permission if I visit the friends and relatives. My husband never seeks my opinion in any matters..." In response to the question regarding decision making, most of participants shared insufficient decision-making power. This finding lends support by another study conducted by Sultana (2011). The author suggests that education, occupation and income have significant effect in explaining the variance in household decision-making power. Educated and employed women tend to have more decision-making power than those who have less education. The author concluded that women education, income, occupation and have a significant effect on household decision-making. A recent study was conducted by Afrouz et al, (2018) on perceptions of teenage women about marriage in adolescence in an Iranian setting. The authors stated that due to young age respondents had a negligible role in decision-making, were forced to leave school, and were totally dependent on their husband or parents, financially. In another study, Zahangir (2011) argued that teenage women have a limited access to financial resources and less power, as compared with adult women, to participate in decisions about their lives.

\section{Lack of Independence}

Because of their early marriage, most of the participants felt a lack of independence $(66.7 \%)$. They did not have any power or role in making major decisions. Since they do not have any employment and income, they need depends on husband and other family members. Hence, they will have no hope of having an income and a better financial and social status in the future. Previous research points to a variety of social, family, health, and financial outcomes that are strongly correlated with early teen marriage and low education. The negative outcomes associated with early marriage have potential effect on dropping out of high school. Dropping out of high school constitutes of lower level of education and employment opportunity. Without sufficient income these women may need to depend on husband and feel lack of independence.

\section{School Drop Out}

Following to the early marriage, most of women tended to drop out of school which affects their ability to access the benefits of education. A 19 years participant who stated " "I was 14 years old. That time I was in secondary school. I told my parents that I am not ready to be married. I want to continue my study. They assured me that after marriage I can continue my study but it was not true. My in-laws refused to continue my study". Early marriage is among the reasons for dropping out of schools in Bangladesh. 


\section{Unfulfilled Dreams}

Regarding unfulfilled dreams although $57.6 \%$ respondents answered "No", a number of respondents expressed disappointment. The participants expressed that they were disappointed and found their dreams had unfulfilled. Some of them could not even continue their education as their husband or his family did not allow them. A 15-year participant who stated "... I wanted to be educated and I wished to have jobs and own income but due to early marriage I could not continue my study..." It has been observed that these women were deprived of education and had no hope of a decent job or a better future. During the depth interview, most of the participants reported that they lost their childhood. These women mostly dissatisfied with the heavy burden of life. The majority of participants stated that due to early marriage they could not continue their studies and therefore there is no hope for finding a good job and better life. In a study, Zahangir (2011) argued that early marriage is a sudden stop to one's childhood, and limit the choices about the future. Afrouz, et al, (2018) argued that the opportunities to play, dream, and acquire knowledge or skills are replaced by responsibilities as a mother, a spouse, and a daughter-in-law.

\section{Marital Satisfaction}

More than half of the participants (51.5\%) expressed dissatisfaction about their marital relationship. They claimed that they did not have any clear image about marital life. They were forced to accept the responsibilities. During the depth interview one 18-year-old woman, explained her three marital life as follows, "Marital life is very hard; managing in law, cooking, taking care of the baby, nothing interesting. Sometimes it is intolerable.

Table 1: Experiences of Teenage Women in Their Marital Relationship

\begin{tabular}{|c|c|c|c|c|c|c|c|c|c|}
\hline \multirow[t]{2}{*}{ No } & \multirow[t]{2}{*}{ Items } & \multicolumn{2}{|c|}{ Yes } & \multicolumn{2}{|c|}{ No } & \multicolumn{2}{|c|}{ Neutral } & \multirow[t]{2}{*}{ Mean } & \multirow{2}{*}{$\begin{array}{l}\text { Std. } \\
\text { Deviation }\end{array}$} \\
\hline & & $\mathrm{N}$ & $\%$ & $\mathrm{~N}$ & $\%$ & $\mathrm{~N}$ & $\%$ & & \\
\hline 1 & $\begin{array}{l}\text { Acceptance of arranged } \\
\text { marriage }\end{array}$ & 26 & 78.8 & 6 & 18.2 & 1 & 3.0 & 4.76 & 16.92 \\
\hline 2 & Decision-making power & 10 & 30.3 & 23 & 69.7 & 0 & 0.0 & 10.21 & 28.52 \\
\hline 3 & Lack of independence & 22 & 66.7 & 11 & 33.3 & 0 & 0.0 & 10.24 & 28.51 \\
\hline 4 & Unfulfilled dreams & 13 & 39.4 & 19 & 57.6 & 1 & 3.0 & 4.55 & 16.96 \\
\hline 5 & Marital Satisfaction & 17 & 51.5 & 15 & 45.5 & 1 & 3.0 & 4.48 & 16.97 \\
\hline 6 & Unwanted pregnancy & 20 & 60.6 & 12 & 36.4 & 1 & 3.0 & 4.58 & 16.96 \\
\hline 7 & School drop out & 17 & 51.5 & 15 & 45.5 & 1 & 3.0 & 4.48 & 16.97 \\
\hline
\end{tabular}

\section{Unwanted Pregnancy}

Unwanted pregnancy is common among young married women. One respondent, Rehena, was pregnant within a year of marriage. She was taking the pill on the advice of her friend, but it made her feel sick. She reported that she could not consider other alternatives, because her husband and other family members she did not allow her. The experiences of individual girls interviewed in the qualitative interviews suggest that it is common for girls to become pregnant without their wills.

\section{Conclusion}

In this paper, we explored young women's experience and perception of early marriage. According to the results, most of participants supported arranged marriage. The results also 
revealed that early marriage impact on decision making, education, unfulfilled dream, unwanted pregnancies and marital satisfaction. Given that early marriage is a negative impact, multidimensional approach is necessary to support and empower these disadvantaged women. There is a greater challenge to traditional beliefs on early marriage in Bangladesh. Parents, community members, and women need to be aware about the negative consequences of early marriage. Expanding training and campaign on the negative impact of early marriage on women are necessary.

\section{Acknowledgments}

Research for this project was supported by Bangladesh Social Development Academy (BSDA). We gratefully acknowledge the study respondents who consented to voluntarily participation in the study and provided valuable information.

\section{References}

Afrouz M, Abbas, E, Z, Behboodi, M, Shirin, S (2018). Perceptions of teenage women about marriage in adolescence in an Iranian setting: A qualitative study. Electronic Physician, 10(2), 6292-6298

Field, E., \& A. Ambrus. (2008). Early Marriage, Age of Menarche, and Female Schooling Attainment in Bangladesh. Journal of Political Economy 116 (5): 881- 930. doi: $10.1086 / 593333$

ICRW (2012). Child Marriage in Asia: Policy options for action. Australian Agency for International Development (AusAID)

Jennifer, P., Jeffrey, E., Aslihan, K., Suzanne, P., Maggie, Sexton, Quentin. W. (2005). Economic Impacts of Child Marriage: A Review of the Literature. The Review of Faith $\begin{array}{llll}\& & \text { International } & \text { Affairs. }\end{array}$ http://dx.doi.org/10.1080/15570274.2015.1075757

Le Strat, Y., C. Dubertret, and B. Le Foll. (2011). Child Marriage in the United States and Its Association with Mental Health in Women. Pediatrics 128 (3): 524-530. doi: 10.1542/peds.2011-0961

Michelle J. Miller (2015). Stop Forced Child Marriage: A Comparative Global Law Analysis. World Academy of Science, Engineering and Technology International Journal of Humanities and Social Sciences. 9 (11), 1-10

Muazzam N., Rubeena, Z, Muhammad Z, Z, Safdar, A, Rabia S, Mahwish S, Alexander, K (2014). Knowledge and attitude towards child marriage practice among women married as children-a qualitative study in urban slums of Lahore, Pakistan. BMC Public Health.14, 1148

Nahid. F. (2013). Child marriage in Bangladesh: Socio-legal analysis. International Journal of Sociology and Anthropology. 6(1), 1-7.

Nguyen, M. C., and Q. Wodon. (2015). Early Marriage, Pregnancies, and the Gender Gap in Education Attainment: An Analysis Based on the Reasons for Dropping out of School. In Child Marriage and Education in sub-Saharan Africa, edited by Q. Wodon. Washington, DC: World Bank

Nour, N. W. (2009). Child Marriage: A Silent Health and Human Rights Issue. Review of Obstetric Gynaecology 2 (1): 51-56

Ooi, K. H (2017). Child Marriages in Malaysia: Reality, Resistance and Recourse. Report published by Penang Institute.

Sultana, A.M. (2010). Socio-Cultural Dimensions of Women Discrimination in Rural Communities. Asian Journal of Social Sciences, 3 (1), 31-37. 
Sultana, A.M. (2011). Factors Effect on Women Autonomy and Decision-Making Power within the Household in Rural Communities. Journal of Applied Sciences Research, 7 (1), 18-22.

Sultana, A.M. \& Md. Abdus Salam. (2018). A Study on Impact of Early Marriage on Women Health in Bangladesh. Journal of Advanced Research in Business, Marketing, And Supply Chain Management. 17 (V 1), 54-60.

UNICEF. (2005). Early marriage: A harmful traditional practice: A statistical exploration, N.Y, USA

UNFPA (2012). Child Marriage Profiles - Senegal. UNFPA.

Zahangir M.S. (2011). Early and Very Early Family Formation in Bangladesh. Thesis. Stockholm University. 